\title{
Embryonic Development of Discus, Symphysodon aequifasciatus Pellegrin, 1904 in Indian Condition
}

\author{
Sambid Swain ${ }^{1,2}$, Paramita Banerjee Sawant ${ }^{1 *}$, J. K. Sundaray ${ }^{3}$, \\ E. M. Chhandaprajnadarsini ${ }^{4}$ and Milind B. Katare ${ }^{1}$ \\ ${ }^{1}$ ICAR-Central Institute of Fisheries Education, Mumbai, India \\ ${ }^{2}$ Centurion University of Technology and Management, Odisha, India \\ ${ }^{3}$ ICAR-Central Institute of Freshwater Aquaculture, India \\ ${ }^{4}$ ICAR-Central Marine Fisheries Research Institute, Kochi, India \\ *Corresponding author
}

Keywords

Embryology,

Hatching,

Development,

Discus

Article Info

Accepted:

18 May 2020

Available Online:

10 June 2020

\begin{abstract}
A B S T R A C T
The experiment was conducted to investigate the embryonic development of discus (Symphysodon aequifasiatus) and determine the time required for major egg developmental stages and hatching. Regular observations were made using optical microscope and the images were recorded using a digital camera attached to the microscope. Important water quality parameters were kept optimal for the hatching of discus eggs. Newly laid eggs were oval-shaped and yellow in colour with an average diameter of $1.37 \pm 0.14 \mathrm{~mm}$. The embryonic development of fertilized eggs was divided into 16 stages and the development of each stage was recorded in times lapse. The result revealed that cleavage occurred after $1 \mathrm{hr}$ after fertilization followed by development of blastula and gastrula at $20.5 \mathrm{hr}$ and $24 \mathrm{hr}$ after fertilization respectively. The period of organogenesis started with the formation of embryonic notochord from $37.5 \mathrm{hrs}$ after fertilization. The appearance of a defined head and tail of the embryo with 19 somites was observed at $40.0 \mathrm{hrs}$ after fertilization, whereas heart beat along with blood circulation appeared after $55.5 \mathrm{hrs}$ after fertilization. The eggs hatched after $69.06 \mathrm{hr}$ after fertilization.
\end{abstract}

\section{Introduction}

Discus (Symphysodon aequifasciatus), a cichlid are mostly found in unpopulated small stream and creek of the Amazonian basin has high marketability due to its attractive colour is considered as a high-value ornamental fish (Santos et al., 2006, Wattley, 1991). It possesses a complex and unique reproductive behavior which involves establishment of breeding territories by the male, selection of mate for pair formation, selection of suitable site or substrate for egg laying and subsequent spawning (Chellappa et al., 2005).

One of the rare characteristics of discus breeding is discus brooder shows parental care and secretes nutritious mucus from its 
epidermis for feeding of hatchlings (Chong et al., 2005). For easy understanding of biology of a species the knowledge of embryology can be considered indispensable tool. Inadequate knowledge about the early life stage of a fish can affect its economic sustainability as it has a major impact on the zoo-technical performance and the survival of the fish.

The knowledge of embryology can not only helpful in locating the spawning areas but also identifying the physiological requirements of the fish which can aid to improvement in culture operation and conservation of the icthytofauna (Godinho et al., 2003; Anjos and Anjos, 2006). For determination of viability and quality of a teleost egg, observing the early developmental stage of the egg is considered as a practical and reliable method (Senhorine, 1993; Vallin and Nissling, 1998).

The developmental period of a fish can be defined as the period in which the developing individual entirely depends on the endonutrients from the yolk of the egg (Liew et al., 2006). The developmental period of the fish depends on the fish species and the environmental conditions. The embryonic phase of a fish which begins with the successful fertilization of the egg and its duration includes the time interval between fertilization and eclosion (Jobling , 2002).For proper understanding the embryonic phase of fishes is divided into two phases.

The first phase is the cleavage phase in which first cell division occurs with the appearance of neural plates and in the second phase embryo becomes noticeable as a vertebrate (Moyle and Cech, 2004).Since a detail embryonic study of discus fish $(S$. aequifasciatus) is scares, the current experiment aims to provide the information about the early developmental stages which will be helpful for the fish breeders and researcher.

\section{Materials and Methods}

Discus brooders (103.4 \pm 9.32g) were procured from the local ornamental fish traders in Mumbai, Maharashtra, India and were transferred to discus rearing facility of ICAR-Central institute of fisheries education, Mumbai. These were acclimatized to captive condition in 10001 glass aquaria fitted with power filter and heater along with adequate aeration facility for 15 days. Fishes were fed with artificial commercial diet comprising of pellet feed and moist feed (Minced Chicken, Beef Liver)@ 6\% and 8\% of their body weight respectively every alternate day. Pre spawning behaviour was observed during this period, after which the pairs were transferred to 1001 breeding tanks for initiating natural spawning. The breeding tanks were also equipped with power filter, thermostat and have aeration facilities for maintaining ideal condition for breeding. PVC tubes of $30 \mathrm{~cm}$ in length were placed in the tank as substrates. The adhesive eggs of discus were found attached to the substrate which was latter scrapped using scrapples and were counted. In order to observe the developmental stage following procedure was followed i) Observation was made every $30 \mathrm{~min}, 60$ mins,90 min from the fertilization till the end of the gastrula phase, start of organogenesis till emergence of heart and emergence of heart till hatching respectively using olympus SZX16 strereozoom microscope ( $15 \mathrm{X}$ magnification) which was photographed digitally by a camera attached the microscope. For each observation one third of the total number of egg was selected randomly which were latter placed in a petri-disc and were observed under the microscope. The eggs were analyzed for quality and those unfertilized and had fungal infection were discarded. The embryonic stages were analyzed based on the recommendations of Reid \& Holdway,1995; Humphrey et al., 2003; Fugimoto et al., 2004; Fujimoto et al., 
(2006); Radael et al., (2013); Mattos et al., 2014. The time at which $50 \%$ of the eggs investigated attained similar stage, the embryonic developmental stage were considered. The important water quality parameters viz. temperature, $\mathrm{pH}$ and dissolved oxygen were measured by thermometer, digital hand held $\mathrm{pH}$ probe on a daily basis., ammonia $\left(\mathrm{NH}_{3}-\mathrm{N}\right)$, nitrite $\left(\mathrm{NO}_{2}-\mathrm{N}\right)$, nitrate $\left(\mathrm{NO}_{3}-\mathrm{N}\right)$, Free carbon dioxide and Total hardness were also measured daily as per the standard protocols of APHA, 1998.

\section{Results and Discussion}

\section{Water quality}

In order to restrict any abrupt water quality parameter the experiment was carried in a closed environmental condition. The physiochemical parameters of water in which the eggs were kept were in the recommended levels via. Temperature, $29.2 \pm 0.04^{\circ} \mathrm{C} ; \mathrm{pH}$, $6.60 \pm 0.12 ; 7.9 \mathrm{mg} / 1 \pm 0.25$; Nitrite levels and total ammonia were never greater than 0.01 $\mathrm{mg}^{-1}$ and $0.3 \mathrm{mg}^{1}{ }^{1}$ respectively over the entire course of the experiment. The mean value observed for alkalinity and hardness were $30 \pm 0.17 \mathrm{mg} \mathrm{CaCO}_{3} \mathrm{l}^{-1}$ and $50 \pm 0.28$ mg $\mathrm{CaCO}_{3} \mathrm{I}^{-1}$ respectively.

\section{Eggs characteristics}

Newly released egg were oval shaped and yellow in colour with an average diameter of $1.37 \pm 0.14 \mathrm{~mm}$. These are adhesive in nature and found attached to a solid substratum. As discus eggs have large amount of yolk they are considered as polilecios.

The organelles are mostly present in the animal pole and the yolk is concentrated at the vegetal pole of the egg. The unfertilized eggs are off white in colour and have a very touch sensitive chorion compared to a fertilized egg (Mattos et al., 2014) (Plate 1).

\section{Embryonic development}

The embryonic developmental stage were described based on the recommendations of Fujimoto et al., 2004; Humphrey et al., 2003 and Reid \& Holdway, 1995. The stages were divided into five major period viz. cleavage, blastula, gastrula, organogenesis and eclosion stage.

\section{Cleavage period}

The period in which the blastomere divide incessantly doubling their numbers in each division until the blastodics has 64 blastomeres is termed as cleavage period (Fujimoto et al., 2004). The $1^{\text {st }}$ cleavage started $1 \mathrm{hr}$ after fertilization where two round blastomeres were formed by the division of blastomere by cleavage plane, right angle to the axis between second polar body and the micropyle. Eight and thirty two blastomeres of equal size were formed due to the division of four and sixteen blastomers was noticed at $3 \mathrm{hr}$ and $5 \mathrm{hrs}$ after fertilization respectively. The final cleavage division occurred at $9.5 \mathrm{hr}$ after fertilization leading to formation of 64 equal blastomeres by mitotic division of 32 blastomers. The final cleavage division resulted in formation of blastodisc with overlapping layers of blastomers.

\section{Blastula period}

A continued existence between the blastoderm and the yolk sac limits was noticed during this stage. Blastula stage occurred after the seventh cleavage which resulted in the formation of 128 bastomere and lasted till the formation of 1024 blastomeres. Four to five layers of blastomeres with more than 2000 cells are noticed within the dome shaped blastoderm at this stage of development. Depending on the position of each blastomers, the blastomers gets divided but the plane of cannot be 
practically observed (Yokoya, 1966). In case of discus eggs this phase progressed from 9.5 hpf till 18.5 hpf during which the eggs became more or less rounded in shape

\section{Gastrula period}

The most distinct characteristics of this stage is the appearance of epibole. The blastoderm expands over the surface of the yolk sac and the embryonic region of the egg can be easily identified as in this stage the blastoderm gets thickened. In the latter stage of Gastula, a well defined germ ring was observed.

A weak but rhythmic movement in the egg was noticed and the blastoderm covers the entire yolk sac region, $10 \%$ of yolk vesicle was covered at $22 \mathrm{hpf}$. About $50 \%$ of the yolk was covered by blastoderm at $28 \mathrm{hpf}$ and $90 \%$ at $32.5 \mathrm{hpf}$. This stage is characterized with the differentiation of embryonic axis which appears as an amber colour line beside the yolk sac margin. Gastrula stage completes covering the yolk by the merging of blastoderm edges which was observed at $33.30 \mathrm{hpf}$ in discus egg.

\section{Organogenesis period}

Organogenesis leads to formation and differentiation of major organelles. In case of discus this phase starts from the gastrula phase during which the embryonic axis was observed.

\section{Differentiation of head and tail}

The embryonic axis differentiated into cephalic and caudal region with the closer of blastomere 33:30 hpf. The separation between the two extreme were clearly marked by the prominence of anterior portion of the embryonic axis. Notable appearance of optic primodium and seven pairs of somites were observed in this stage.

\section{Eye development}

Rudimentary eye vesicles resulted due to the evagination of cephalic region of the embryonic axis were formed on each side of the cephalic region in the embryo at $35.0 \mathrm{hpf}$. A well-defined and evident ocular vesicle was noted at $39.5 \mathrm{hpf}$.

\section{Somites formation}

Somites are rudimentary structures that are precursor of vertebrate, ribs and axial musculature of the animal. In S.aequifasciatus embryos they were initially observed at 33.30 hpf. In the latter period these somites increase in numbers i.e 10 pairs were observed at 35 hpf and 19 pairs at $41.5 \mathrm{hpf}$.

\section{Embryonic pigmentation}

Early signs of the pigmentation were observed as small melanophores in the yolk at 39.5 hpf. Consequently, more number of melanopores was found to be concentrated in the dorsal portion of the yolk and also in the ventral region of the embryo.

\section{Circulatory system}

In discus early circulatory system consists of a rudimentary heart which showed early cardiac movement at $45.5 \mathrm{hpf}$ but it was not possible to ascertain the blood circulation. At $56.0 \mathrm{hpf}$ the blood of discus embryo gets pigmented and the blood circulation was easily observed.

\section{Muscle contraction}

Very slow muscle contraction was observed at $53.0 \mathrm{hpf}$. Gradually the contraction gets vigorous with the progress of time, noticeable contraction was observed at $56.5 \mathrm{hpf}$. There is an intensification of the contraction till hatching which caused disruption of chorin leading to hatching of the egg. 


\section{Eclosion}

Vigorous muscle contraction was observed which resulted in breaking of chorion. Hatching occurred at $61.10 \mathrm{hpf}$. The early hatchling had an underdeveloped digestive system without a well-defined mouth which was recognizable at $83.0 \mathrm{hpf}$.

A discus egg poses similar external morphology as shown by the eggs of other cichlid family viz. Astronotus ocellatus eggs. Paes et. al. (2012). Discus eggs are adhesive in nature which can be related to eggs of Cichlasoma dimerus (Meijide \& Guerrero, 2000).The adhesive nature of eggs is considered as an survival strategy adopted by many fish species Nakatani et al., (2001).In the present study, a reduction in blastomere was observed at the beginning of embryonic development in the cleavage stage which coincides with the study of Puvaneswari et al., (2009) in of Heteropneustes fossilis. The development o blastula took a longer period when compared with other fish species such as Betta splendens (Duarte et al., 2012), Melanotaenia praecox (Radael et al., 2013) and Glossolepis incisus (Ferreira, 2007).The start of organogenesis was marked with the differentiation of embryonic axis after the gastrula period, similar observations were reported by Humphrey et al., (2003) in Melanotaenia splendid.

With the meeting of the two edges of the blastomere, the closer of the blastomere was established which is observed at the end of epibole stage concurrent to the studies of Puvaneswari et al., (2009) and ReynalteTataje et al., (2004) in Heteropneustes fossilis and Brycon orbignyanus respectively. The closer of blastopore is considered as a significant stage in the embryonic development in which decides the success of fertilization of the oocyte. Woynarovich \& Horváth, 1983. Head and tail was observed more evident after beginning of segmentation. In Channa striatus, head and tail differentiation reported approximately $11 \mathrm{hpf}$ (Marimuthu\&Haniffa,2007).

Table.1 The range of the water quality parameters observed during experimental period

\begin{tabular}{|l|c|}
\hline \multicolumn{1}{|c|}{ Water quality parameters } & \multicolumn{1}{c|}{ Range } \\
\hline Temperature $\left({ }^{\mathbf{C}} \mathbf{C}\right)$ & $\begin{array}{l}\text { As per } \\
\text { Experimental } \\
\text { Design }\end{array}$ \\
\hline Dissolved oxygen $\left(\mathbf{m g l}^{-\mathbf{1}}\right)$ & $5.2-6.8$ \\
\hline Free carbon dioxide $\left(\mathbf{m g l}^{-\mathbf{1}}\right)$ & $0-4$ \\
\hline Total hardness $\left(\mathbf{m g l}^{-\mathbf{1}}\right)$ & $48-62$ \\
\hline Ammonia-nitrogen $\left(\mathbf{N H}_{\mathbf{3}}-\mathbf{N}\right)$ & $0.01-0.04$ \\
\hline Nitrite-nitrogen $\left(\mathbf{N O}_{\mathbf{2}}-\mathbf{N}\right)$ & $0-0.02$ \\
\hline Nitrate-nitrogen $\left(\mathbf{N O}_{\mathbf{3}}-\mathbf{N}\right)$ & $0.48-2.13$ \\
\hline
\end{tabular}




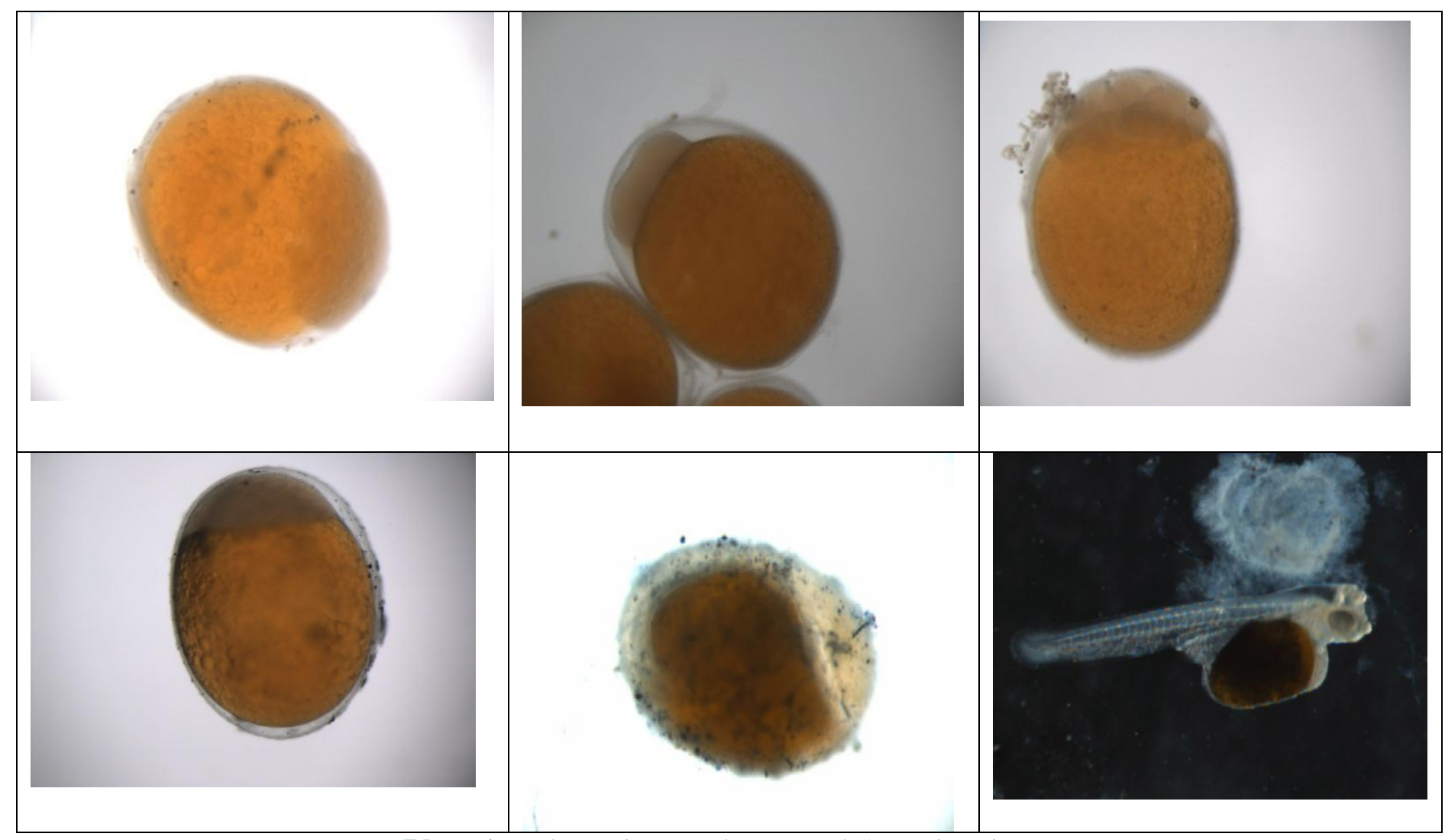

Plate.1 Embryonic Developmental Stage in Discus

(A) Recently fertilized egg with only one blastomere (B) 4 cell embryonic stage

(C) Blastula Stage (D) Gastrula (E) Organogenesis (F) Hatchlings

Discus larvae are typical example of altricial larvae where hatching of discus eggs takes place even before the complete formation of the embryo identical feature was recorded in neotropial larvae Nakatani et al., (2001).The larvae were found adhered to the substrate after the eclosion of the eggs by adhesive substance secreted by glands located in the base of eye and head, which is considered as a strategy to minimize scattering of larvae into the water column .The above strategy followed are associated to parental care observed in discus, similar observation $\mathrm{s}$ are noticed in other fish species like Cichlasoma dimerus (Meiji de \& Guerrero, 2000) and Astronotus ocellatus by Paes et. al., (2012). The ocular structure of discus developed in a similar fashion as reported in other species and it was attained at $46.5 \mathrm{hpf}$. In case of M. praecox and tilapia (Oreochromis niloticus), the optic primodium was formed at $21.89 \mathrm{hpf}$ and $44 \mathrm{hpf}$ as reported by Radael et al., (2013) and Okada (2007) respectively. Early hatching had un pigmented and under developed eyes, eventually after the yolk absorption stage the eyes were pigmented and was fully developed. From this experiment it can be noted that discus eggs hatches at 61.10 hpf and have similar characterstics as shown by other cichlids species.

\section{References}

Anjos, H.D.B. and Anjos,C.R., 2006. Reproductive biology and embryonic and larval development of the cardinal tetra, Paracheirodon axelrodi Schultz, 1956 (Characiformes: Characidae), in laboratory. Bol. Inst. Pesca, 32, 151166. 
Chellappa, S., Câmara, M. R. and Verani.J. R., 2005. Ovarian development in the amazonian red discus, Symphysodon discus, Heckel (Osteichthyes: Cichlidae). Brazilian Journal of Biology, 65, 609-616

Chong, K., Ying, T.S., Foo, J., Jin, L.T and Chong, A., 2005. Characterization of proteins in epidermal mucus of discus fish (Symphysodon spp.) during parental phase. Aquaculture 249, 469476.

Duarte, S.C., Vasconcellos, B.F., Vidal Jr., M.V., Ferreira, A.V., Mattos., D.C. and Branco, A.T., 2012. Ontogeny and embryonic description of Betta splendens, Perciformes (Regan, 1910). Revista Brasileira de Saúde e Produção. Animal 13, 880-93.

Ferreira, A.V., 2007. Ontogenia Inicial E Consumo De Vitelo Em Embriões De Melanotaenia Maçã (Glossolepis incisus, Weber, 1907). Dissertação. Universidade Estadual do Norte Fluminense Darcy Ribeiro, Campos dos Goytacazes., $64 \mathrm{pp}$

Fujimoto, T, Kataoka, T, Sakako, S., Saito, T. Yamaha, $\mathrm{E}$ and Arai, K. 2006.Developmental stages and germ cell lineage of de loach (Misgurnusan guillicaudatus). Zoological Society of Japan, v.23. p.977-989.

Fujimoto, T, Kataoka., T, Otani, S., Saito, T., Aita, T., Yamaha,E. and Arai, K., 2004. Embryonic stages from cleavage to gastrula in the loach Misgurnusan guillicaudatus. Zoolog.Sci.Jpn 21, pp. 747-755.

Godinho, H.P., Santos, J.E. and Sato, Y., 2003. Ontogênese larval de cinco espécies de peixes do São Francisco, pp.133-148. In H.P. Godinho \& A.L. Godinho (eds.). Águas, Peixes $e$ Pescadores do São Francisco das Minas Gerais. Belo Horizonte: PUC Minas, 468 pp.
Humphrey, C., Klumpp, D. W. and Pearson, R., 2003.Early development and growth of the east rainbowfish, Melanotaenia splendida splendid (Peters). I. Morphogenesis and ontogeny. Mar. Freshwater Res.54, 17-25.

Joblin, M.,2002 . Environmental factors and rates of development and growth. P.J.B. Hart, J.D. Reynolds (Eds.), Handbook of Fish Biology and Fisheries, vol. 1, Fish Biology Blackwell Science Ltd. Blackwell Publishing Company.

Liew, H. J., Ambak, M. A., and Abol-Munafi, A. B., 2006. Embryonic development of clownfish Amphiprion ocellaris under laboratory conditions. Journal of Sustainable Science and Management, 1(1), 64-73.

Marimuthu, K. and Haniffa, M.A., 2007. Embryonic and larval development of the striped snakehead Channa striatus. Taiwania.52, 84-92.

Mattos,D.C, Leonardo, D. C, Paulo José Fosse, M. C., Radael, J. C., Fosse, F., JoãoVitor, Dalcio, R.A and Manuel, V. V., 2014. Description of the ontogenic and larval period of discus fish (Symphysodona equifasciatus).Zygote. 7, 7-11.

Meijide, F.J and Guerrero, G.A., 2000. Embryonic and larval development of a substrate-brooding cichlid Cichlasoma dimerus (Heckel, 1940) under laboratory conditions. J. Zool.252, 48193.

Moyle, P.B and Cech, J.J.J.R., 2004. Fishes: an introduction to ichthyology, 5th edn. Pearson Prentice-Hall Inc. Upper Saddle River, NJ, 82-96.

Okada, N and Fujimura, K., 2007. Development of the embryo, larva and early juvenile of Nile tilapia Oreochromis niloticus (Pisces: Cichlidae). Dev. Growth Diff. 49, 301-24.

Paes, M.C.F., Makino, C.L., Vasquez, A.L., Fernandes, K.B.J. and Nakaghi, O.S.L., 
2012. Early development of Astronotus ocellatus under stereomicroscopy and scanning electron microscopy. Zygote, 20, 269-76.

Puvaneswari, S., Marimuthu, K., Karuppasamy, R. \& Haniffa, A.M., 2009. Early embryonic and larval development of Indian catfish, Heteropneustes fossilis. EurAsianJ. BioSci. 3, 84-96.

Radael,M.C, Leonardo, D. C, Dalcio Ricardo, A.D.M, Jonas, Henrique Motta, JoãoVitorManhães and Manuel, V. V., $2013 . \quad$ Morphophysiological characterization of the embryonic development of Melanotaenia praecox (Weber \& de Beaufort, 1922).Zygote, 533-539.

Reid, H.P and Holdway, D.A., 1995. Early development of the Australian crimson spotted rainbowfish, Melanotaenia fluviatilis (Pisces: Melanotaeniidae). Marine and Freshwater Research, 46 : $475-480$

Reynalte-Tataje, D., Zaniboni-Filho, E. and Esquivel, J.R., 2004. Embryonic and larvae development of piracanjuba,
Bryconorbignyanus Valenciennes, 1849 (Pisces, Characidae). Acta Scientiarum. Biol. Sci.26, 67-71.

Santos, G., Ferreira, E. and Zuanon, J., 2006. Peixes comerciais de Manaus. Manaus, Ibama. AM, Provárzea. 144 pp.

Senhorine, J.A., 1993. Procedimento para criação de larvas de peixes. IBAMACEPTA. Pirassununga - São Paulo. Apostila $21 \mathrm{pp}$.

Vallin, L. and Nissling, A., 1998. Cell morphology as an indicator of viability of cod eggs - results from an experimental study. Fisheries Research, 38, 247-255.

Wattley, J., 1991. Discus for the Perfectionist. T.F.H Publications, $125 \mathrm{pp}$.

Woynarovich, E. and Horváth, L., 1983. A Propagação Artificial de Peixes de águas tropicais: Manual de Extensão. Brasília:FAO/CODEVASF/CNP, 13 pp.

Yokoya, S., 1966. Cell dissociation and reaggregation in early stage embryo of a teleost, Oryzias latipes. Scient. Rep. Tohoku Univ. (Ser. IV, Biol.), 32, 229236

\section{How to cite this article:}

Sambid Swain, Paramita Banerjee Sawant, J. K. Sundaray, E. M. Chhandaprajnadarsini and Milind B. Katare. 2020. Embryonic Development of Discus, Symphysodon aequifasciatus Pellegrin, 1904 in Indian Condition. Int.J.Curr.Microbiol.App.Sci. 9(06): 2170-2177. doi: https://doi.org/10.20546/ijcmas.2020.906.265 